\title{
Knowledge and attitudes towards COVID-19 among emergency medical service workers
}

\author{
Asli Vatan ${ }^{1}$ \\ (D) Ertuğrul Güçlür \\ (iD) Aziz Öğütlür \\ (iD) Fulya Aktan Kibar ${ }^{2}$ \\ (iD) Oğuz Karabay'
}

1. Department of Infectious Diseases and Clinical Microbiology, Sakarya University Training and Research Hospital, Sakarya, Turkey. 2. Department of Public Health, Sakarya University Training and Research Hospital, Sakarya, Turkey.

http://dx.doi.org/10.1590/1806-9282.66.11.1553

\section{SUMMARY}

OBJECTIVE: Good knowledge of the coronavirus disease 2019 (COVID-19) among healthcare workers is essential for keeping health systems active and controlling the outbreak. We aimed to investigate the knowledge and attitudes of Emergency Medical Service (EMS) employees who fight COVID-19 at the forefront.

METHODS: A total of 400 EMS workers (doctors, nurses, emergency medical technicians, paramedics, and ambulance drivers) were included in this study. Knowledge, attitude, and preventive behaviors for COVID-19 were evaluated using an online questionnaire.

RESULTS: A total of 275 EMS workers participated in the study with a response rate of $68.8 \%$. The respondents reported that their highest common sources of knowledge about COVID-19 were social media and television ( $n=240,88 \%$ ). Overall, $>96 \%$ of the participants had adequate knowledge about the transmission routes of COVID-19. Among the respondents, 36\% of them were unaware of the correct hand washing or scrubbing technique. In addition, $78 \%$ of the participants had poor knowledge about floor and surface disinfection. The majority of the participants exhibited inaccurate attitudes toward the use of personal preventive equipment. More than half of EMS workers (52\%) agreed that a surgical mask is not enough during the procedures that do not generate aerosol. Moreover, a significant proportion of the participants (66\%) perceived that a N95 mask is required.

CONCLUSIONS: As a consequence, although emergency workers have sufficient basic knowledge about COVID-19, there is a need for postgraduate training in many subjects.

KEYWORDS: coronavirus disease 2019, emergency medical service, knowledge and attitudes, questionnaire

\section{INTRODUCTION}

COVID-19 initially manifested as a cluster of pneumonia cases of unknown etiology in Wuhan, Hubei Province of China on 31 December 2019'. The causative agent was identified as a novel coronavirus that had not been previously seen in humans ${ }^{2}$. The World Health Organization (WHO) determined a new name for the epidemic disease caused by this virus - coronavirus disease 2019 (COVID-19) and on January $30^{\text {th }}$, declared the coronavirus outbreak a Public Health Emergency of International Concern ${ }^{3}$.

According to the current evidence, the main routes of transmission are human-to-human via respiratory

DATE OF SUBMISSION: 27-JUn-2020

DATE OF ACCEPTANCE: 26-Aug-2020

CORRESPONDING AUTHOR: Asli Vatan

Sakarya University Training and Research Hospital, Adnan Menderes Street, 54000, Sakarya, Turkey

Tel: +90 5302889936 / Fax: +90 2642759192

E-mail: asli_oner@hotmail.com 
droplets, direct contact, or fomites ${ }^{4}$. The common clinical manifestations of the disease are fever, dry cough, shortness of breath and bilateral patchy infiltrates on imaging ${ }^{4}$. The fatality rate of the COVID-19 is currently reported as approximately $4 \%$, which is much lower than that of the Severe Acute Respiratory Syndrome (SARS) and Middle East Respiratory Syndrome (MERS) ${ }^{5}$.

Healthcare professionals who are at the front line of the COVID-19 outbreak fight are at high risk of contracting the infection ${ }^{6}$. In a study from China, the rate of transmission to health professionals found was $29 \%$. Data from China's National Health Commission showed that more than 3,300 healthcare workers have been infected as of early March. In Italy, 20\% of responding healthcare workers were infected, and some have died ${ }^{8}$.

Emergency medical service (EMS) workers are first responders who anticipate close contact with affected persons, thus, EMS workers are expected to be at high risk of COVID-19 infection. It is very important for the EMS staff to have knowledge about this disease as they need to respond quickly and closely to COVID19 patients in a narrow area within the ambulance. However, unlike managing a patient in the controlled environment of hospitals, care and transport by EMS present distinct challenges because of the nature of the setting, enclosed area during transport, frequent need for rapid medical response, interventions with limited medical information. Therefore, insufficient knowledge and awareness regarding COVID-19 in the field of EMS is associated with an increased risk of contracting the infection. In addition, this situation can negatively affect the level of anxiety of EMS personnel and the appropriateness of their medical decisions ${ }^{9}$.

In this study, we aimed to investigate the knowledge and attitudes of EMS workers about COVID-19.

\section{METHODS}

\section{Participants}

In total, 400 EMS workers (doctors, nurses, emergency medical technicians, paramedics, and ambulance drivers) were employed in Sakarya province. An online questionnaire was sent to EMS workers via their e-mail accounts. The study was performed per the ethical considerations of the Helsinki Declarations. The Ethics Committee of the Sakarya University School of Medicine approved this study.

\section{Questionnaire}

The study questionnaire was administered 2 weeks after the start of the COVID-19 outbreak, between 1-15 April in Turkey. The survey questions were designed based on the recommendations of the World Health Organization (WHO) and modified from previously published research articles ${ }^{10,11}$. The survey consisted of two sections with 51 question items. The first section of the questionnaire consisted of five questions to assess the socio-demographic characteristics of the participants such as gender, age, level of education, employment status, and profession; another section of the questionnaire included 46 questions to determine their knowledge about the diagnosis and management of COVID-19, personal protection measures, risk perception, and attitude of EMS workers. Knowledge and attitude were assessed by asking two Multiple Choice Questions (MCQ), and the remaining 44 questions were assessed through five Likert-type scales use statements. The response scales use anchors such as 1 = Strongly Agree, 2 = Agree, 3 = Neutral, 4 = Disagree, $5=$ Strongly Disagree.

\section{Statistical analysis}

Statistical analysis was performed using SPSS for Windows version 23.0 (SPSS Inc., Chicago, Ill., USA). Continuous variables are expressed as mean \pm SD or median and interquartile ranges (IQR) according to whether they exhibited a Gaussian distribution. Categorical variables are expressed as proportions and/or percentages. The $\chi 2$ test was performed to determine the associations between the categorical variables.

\section{RESULTS}

This survey was sent to 400 EMS workers. Responses were received from 275 (68.8\%) participants, incuding emergency medical technicians $(\mathrm{n}=108 ; 39.3 \%)$, paramedics $(\mathrm{n}=138 ; 50.2 \%)$, doctors $(\mathrm{n}=8 ; 2.9 \%)$, and ambulance drivers $(\mathrm{n}=21 ; 7.6 \%)$. The demographic characteristics of the participants are summarized in Table 1.

The main source of COVID-19 information was social media $(\mathrm{n}=120,43.6 \%)$ and television $(\mathrm{n}=120$, $43.6 \%)$, followed by training seminars $(n=21,7.6 \%)$, medical books and journals $(\mathrm{n}=8,2.9 \%)$, and newspapers $(\mathrm{n}=6,2.2 \%)$.

Table 2 demonstrates the items related to COVID19 knowledge. The responders who were high school graduates had higher percentages of correct answers 
TABLE 1. DEMOGRAPHIC CHARACTERISTICS OF EMS WORKERS.

\begin{tabular}{|c|c|c|c|c|}
\hline Variables & $\begin{array}{l}\text { Emergency medical technician } \\
\mathrm{N}=108(\%)\end{array}$ & $\begin{array}{l}\text { Paramedics } \\
\mathrm{N}=138(\%)\end{array}$ & $\begin{array}{l}\text { Doctors } \\
\mathrm{N}=8(\%)\end{array}$ & $\begin{array}{l}\text { Ambulance drivers } \\
N=21(\%)\end{array}$ \\
\hline \multicolumn{5}{|l|}{ Age } \\
\hline$\leq 29$ years & $89(88.4 \%)$ & $36(26.1 \%)$ & $6(75 \%)$ & $10(47.6 \%)$ \\
\hline 30-39 years & $18(16.7 \%)$ & $101(73.2 \%)$ & $2(25 \%)$ & $10(47.6 \%)$ \\
\hline 40-49 years & $1(0.9 \%)$ & $1(0.7 \%)$ & - & $1(4.8 \%)$ \\
\hline \multicolumn{5}{|l|}{ Gender } \\
\hline Male & $39(36.1 \%)$ & $43(31.2 \%)$ & $6(75 \%)$ & $19(90.5 \%)$ \\
\hline Female & $69(63.9 \%)$ & $95(68.8 \%)$ & $2(25 \%)$ & $2(9.5 \%)$ \\
\hline \multicolumn{5}{|l|}{ Experience } \\
\hline $1-5$ years & $60(55.6 \%)$ & $1(0.7 \%)$ & $7(87.5 \%)$ & $16(76.2 \%)$ \\
\hline $6-10$ years & $31(28.7 \%)$ & $46(33.3 \%)$ & $1(12.5 \%)$ & $4(19 \%)$ \\
\hline 10-15 years & $12(11.1 \%)$ & $70(50.7 \%)$ & - & $1(4.8 \%)$ \\
\hline $16-20$ years & $5(4.6 \%)$ & $21(15.3 \%)$ & - & - \\
\hline
\end{tabular}

TABLE 2. KNOWLEDGE ABOUT COVID-19 AMONG EMS WORKERS.

\begin{tabular}{|c|c|c|c|}
\hline Questions & $\begin{array}{l}\text { Strongly Disagree/ } \\
\text { Disagree }\end{array}$ & Neutral & $\begin{array}{l}\text { Strongly Agree/ } \\
\text { Agree }\end{array}$ \\
\hline 1. COVID-19 can be fatal? & $36(13.1 \%)$ & $41(14.9 \%)$ & $198(72.0 \%)$ \\
\hline 2. Molecular tests can be used for the diagnosis of COVID-19 & $21(7.6 \%)$ & $72(26.2 \%)$ & $182(56.2 \%)$ \\
\hline $\begin{array}{l}\text { 3. Hands should be washed with soap and water for } 20 \text { seconds to prevent the } \\
\text { spread of infection }\end{array}$ & $99(36.0 \%)$ & $5(1.8 \%)$ & $171(62.2 \%)$ \\
\hline 4. The first-line therapy for COVID-19 is antibiotics & $120(\% 43.6)$ & $88(\% 32.0)$ & $67(24.4 \%)$ \\
\hline 5. A COVID-19 vaccine has started to be administered & $213(77.5 \%)$ & $46(16.7 \%)$ & $16(\% 5.8)$ \\
\hline 6. COVID-19 is resistant to sanitizers containing at least $70 \%$ alcohol & $137(49.8 \%)$ & $77(28.0 \%)$ & $61(22.2 \%)$ \\
\hline 7. The estimated Incubation period for COVID-19 is about 2-14 days & $4(1.4 \%)$ & $12(4.4 \%)$ & $259(94.2 \%)$ \\
\hline $\begin{array}{l}\text { 8. COVID-19 is more severe in those with underlying diseases (hypertension, diabe- } \\
\text { tes, cancer...) }\end{array}$ & $6(2.2 \%)$ & $4(1.5 \%)$ & $265(96.3 \%)$ \\
\hline 9. Most patients infected with COVID-19 develop severe acute respiratory illness & $3(1.1 \%)$ & $10(3.6 \%)$ & $262(95.3 \%)$ \\
\hline $\begin{array}{l}\text { 10. Contact isolation measures should be taken by healthcare professionals while } \\
\text { caring for patients with COVID-19 }\end{array}$ & $2(0.7 \%)$ & $6(2.2 \%)$ & $267(97.1 \%)$ \\
\hline $\begin{array}{l}\text { 11. Droplet isolation measures should be taken by healthcare professionals while } \\
\text { caring for patients with COVID-19 }\end{array}$ & $2(0.7 \%)$ & $7(2.5 \%)$ & $266(96.8 \%)$ \\
\hline $\begin{array}{l}\text { 12. Airborne isolation measures should be taken by healthcare professionals while } \\
\text { caring for patients with COVID-19 }\end{array}$ & $1(0.4 \%)$ & $9(3.3 \%)$ & $265(96.3 \%)$ \\
\hline $\begin{array}{l}\text { 13. A surgical mask is sufficient during operations that do not cause aerosolization in } \\
\text { contact with COVID-19 infected patients }\end{array}$ & $144(52.4 \%)$ & $55(20.0 \%)$ & $76(27.6 \%)$ \\
\hline $\begin{array}{l}\text { 14. N95 masks are required during operations that do not cause aerosolization in } \\
\text { contact with COVID-19 infected patients }\end{array}$ & $41(14.9 \%)$ & $50(18.2 \%)$ & $184(66.9 \%)$ \\
\hline 15. A patient infected with COVID-19 should wear a surgical mask & $83(30.2 \%)$ & $54(19.6 \%)$ & $138(50.2 \%)$ \\
\hline 16. A patient infected with COVID-19 should wear a N95 mask & $95(34.5 \%)$ & $50(18.2 \%)$ & $130(47.3 \%)$ \\
\hline
\end{tabular}

than those with a bachelor's degree (p:<0.001). Their knowledge also differed significantly according to work experience. Participants with less than 10 years of experience had much more wrong answers than the ones with more than 10 years of experience (p: $<0.001$ ).

In the section on the attitude of healthcare workers, there were 16 items. Table 3 summarized the attitude and preventive behaviors of EMS workers toward COVID-19.

\section{DISCUSSION}

Healthcare professionals who are fully aware and knowledgeable about COVID-19 are essential for keeping health systems active and controlling the outbreak. It is very important to know EMS's knowledge of and attitudes toward the pandemic since they fight COVID19 at the forefront and the risk of health personnel getting infected is high when necessary precautions are not taken. On the $29^{\text {th }}$ of April, the Republic of Turkey Ministry of Health declared that 7,428 health 
TABLE 3. ATTITUDE AND PREVENTIVE BEHAVIORS OF EMS WORKERS TOWARD COVID-19.

\begin{tabular}{|c|c|c|c|}
\hline Questions & $\begin{array}{l}\text { Strongly Disagree/ } \\
\text { Disagree }\end{array}$ & Neutral & $\begin{array}{l}\text { Strongly Agree/ } \\
\text { Agree }\end{array}$ \\
\hline $\begin{array}{l}\text { 1. The prevalence of COVID- } 19 \text { can be prevented by applying the universal recom- } \\
\text { mendations given by the Turkey Ministry of Health and WHO }\end{array}$ & $3(1.1 \%)$ & $63(22.9 \%)$ & $209(76.0 \%)$ \\
\hline $\begin{array}{l}\text { 2. The transmission of COVID-19 to healthcare staff can be reduced by applying } \\
\text { the precautions of the hospital infection control committee }\end{array}$ & $9(3.3 \%)$ & $30(10.9 \%)$ & $236(85.8 \%)$ \\
\hline 3. Patients with suspected or confirmed COVID-19 should be kept in isolation & $0(0.0 \%)$ & $4(1.5 \%)$ & $271(98.5 \%)$ \\
\hline 4. I have sufficient knowledge about protective measures against COVID-19 & $23(8.4 \%)$ & $67(24.4 \%)$ & $185(67.2 \%)$ \\
\hline 5. I think that an in-hospital training program on COVID-19 is beneficial & $35(12.7 \%)$ & $85(30.9 \%)$ & $155(56.4 \%)$ \\
\hline 6. Health professionals should have adequate knowledge about COVID-19 & $3(1.1 \%)$ & $4(1.5 \%)$ & $268(97.5 \%)$ \\
\hline $\begin{array}{l}\text { 7. All patients with a confirmed diagnosis of COVID-19 should be admitted to the } \\
\text { intensive care unit }\end{array}$ & $194(70.5 \%)$ & $33(12.0 \%)$ & $48(17.5 \%)$ \\
\hline 8. Gargling or nose wash with saltwater protects against COVID-19 & $114(41.5 \%)$ & $89(32.4 \%)$ & $72(26.1 \%)$ \\
\hline 9. Consuming bounty soup is effective in the prevention of COVID-19 & $97(35.3 \%)$ & $85(30.9 \%)$ & $93(33.8 \%)$ \\
\hline 10. Antiviral prophylaxis against COVID-19 should be required & $117(42.5 \%)$ & $103(37.5 \%)$ & $55(20.0 \%)$ \\
\hline 11. Vitamin C supplements were effective in the prevention of COVID-19 & $25(9.1 \%)$ & $79(28.7 \%)$ & $171(62.2 \%)$ \\
\hline 12. Vitamin D supplements were effective in the prevention of COVID-19 & $40(14.5 \%)$ & $97(35.3 \%)$ & $138(50.2 \%)$ \\
\hline $\begin{array}{l}\text { 13. Consuming a mixture of honey and propolis is effective in the prevention of } \\
\text { COVID-19 }\end{array}$ & $33(12.0 \%)$ & $102(37.1 \%)$ & $140(50.9 \%)$ \\
\hline 14. I am worried about being infected with COVID-19 & $42(15.3 \%)$ & $34(12.4 \%)$ & $199(72.4 \%)$ \\
\hline 15. I feel under pressure as I can carry COVID-19 to my family & $8(2.9 \%)$ & $10(3.6 \%)$ & $257(93.5 \%)$ \\
\hline 16. Social isolation is negatively affecting my mental health & $59(21.4 \%)$ & $42(15.3 \%)$ & $174(63.3 \%)$ \\
\hline
\end{tabular}

workers had been infected with COVID-19. This number corresponds to $6.5 \%$ of the total COVID-19 cases in Turkey $^{12}$. In this study, various topics such as level of knowledge about COVID-19, personal protection measures, risk perception, and attitude of EMS workers were explored. To the best of our knowledge, this is the first study assessing these topics in EMS workers on COVID-19 infection.

This survey was sent to 400 EMS workers and 275 (response rate 69\%) participants answered the questionnaire. This rate is lower than similar surveys that have been conducted before. The low participation might be attributed to the overload of stressful work of the EMS staff.

In our study, social media and television were the main sources of participant's knowledge (88\%). This result is compatible with previous studies ${ }^{10,13}$. A study by Prescott K. showed that the role of social media in providing information about COVID-19 was rather low in England $(19 \%)^{14}$. This low rate might be due to the fact that the study was conducted at a time when the cases in the UK were just emerging.

In our study, the reason why social media is the main tool as a source of information may be that it is more accessible and practical than other online resources such as scientific journals and books. Moreover, the 'principle of least effort' might direct people to social media as a source of knowledge. On the other hand, the spread of fake science via social media has been demonstrated, considering that 'The social media panic moved faster than the COVID-19 outbreak ${ }^{\mathfrak{1 5 , 1 6}}$. Previous studies demonstrated that at least $40 \%$ of information shared on social media is fake, of which $20 \%$ is "dangerously" fake ${ }^{17}$. As a result of such issues, the WHO had to take some actions to guarantee that this virus would not spark a critical social media infodemic" which is triggered by wrong information ${ }^{18}$.

One of the most important topics that EMS workers should know is hand hygiene and antisepsis. Ensuring hand hygiene all the time is regarded as the most effective preventive measure against infection ${ }^{19}$. In this study, 36\% of the responders were unaware of the correct hand washing or rubbing technique. In addition, we found that $78 \%$ of the participants had poor knowledge about floor and surface disinfection. There was also a significant variation in correct replies among participants with different educational levels. Responders who were high school graduates answered questions correctly with higher percentages than those with a bachelor's degree, probably because they are less well aware of the topic $(p<0.001)$. Their knowledge also differed significantly according to work experience. Participants having less than 10 years of experience had much more wrong answers than the ones with more than 10 years of experience $(p<0.001)$. Based on these results, we concluded that 
the knowledge gap among EMS workers about hand hygiene and surface disinfection should be eliminated in the case of a next potential pandemic. Thus, standardized postgraduate education programs with a module focused on infection prevention, such as hand hygiene, or evidence-based strategies for the prevention of a specific type of infection are crucial.

Contact and droplet precautions should be always applied by healthcare workers caring for patients with COVID-19. Furthermore, airborne precautions should be implemented for aerosol-generating procedures. National COVID-19 guidelines for infection prevention and control suggest that wearing a surgical mask is efficient during the transport of suspected COVID-19 patients to the referral health care facility. However, EMS workers who are providing direct care to COVID19 patients in settings where aerosol-generating procedures are frequently in place should wear N95, FFP2, or FFP3 masks ${ }^{20}$.

Despite national guideline suggestions, most of the respondents who participated in our study chose to raise the level of prevention measures despite the national guideline suggestions. $52 \%$ of the EMS workers agreed that a surgical mask is not enough during the procedures that do not generate aerosol. Moreover, a significant proportion of the participants perceived that a N95 mask is required (66\%). However, a recent study demonstrated that $85 \%$ of healthcare workers in Iran believed that a surgical mask is effective for the prevention of COVID-19 on the procedures that do not generate aerosols. The difference of findings between the two studies may be related to several fake news on Turkish media that indicated that surgical masks were ineffective against COVID-19. This conflicting information may lead to anxiety and distress for healthcare workers. This situation develops unfavorable mental health outcomes that might affect their decisions on proper care. Thus, in our study, $20 \%$ of respondents who were frontline workers against COVID-19 had no idea about wearing an appropriate mask.

Currently, there are no approved curative treatments or a vaccine to prevent or treat COVID-19. There are lots of news that have not been based on scientific evidence, such as that dietary supplements are effective in preventing COVID-19, which has been featured in social media. Therefore, people are looking for alternative nutritional supplements to strengthen their immune system in order to protect themselves from this virus. In our study, $62 \%$ of the EMS workers agreed that Vitamin C supplements were effective in preventing COVID-19. Furthermore, 50\% of respondents believed that taking Vitamin D supplements were mandatory to protect themselves from COVID19. Previous studies showed that a high dose of Vitamin $\mathrm{C}$ administration might be associated with a lower incidence of pneumonia in restricted population groups ${ }^{21}$. However, two recently published open-label studies relating to the use of vitamin $\mathrm{C}$ in different types of infections, associated with septic shock and acute respiratory distress syndrome (ARDS), demonstrated that using Vitamin $\mathrm{C}$ as a monotherapy or in combination with hydrocortisone, and thiamine had provided no significant benefit ${ }^{22,23}$. Thus, there is no robust scientific evidence to support the use of this vitamin in the management of COVID-19.

There is a limited number of studies on the use of vitamin D in COVID-19. Some of these reported that higher vitamin D3 doses might be useful for treating people who become infected with COVID-19 ${ }^{24,25}$. However, they indicated that randomized controlled trials and large population studies should be conducted to evaluate this recommendation. Thus, Vitamin D supplementation is mentioned as a potentially beneficial treatment for COVID-19 infection but, on a scientific basis, with a low level of evidence until now. Even if there has been no approved effectiveness of these products, people's instincts have led them to take some actions such as taking nutritional supplements.

In order to defend themselves from COVID-19, a significant proportion of participants agreed that gargling with salty water (56\%), drinking bounty soup $(64 \%)$, and eating a honey and propolis mixture (88\%) can be protective. Since the beginning of this pandemic, some television programs in our country have argued that such suggestions will help to protect from this disease. Although there is no scientific evidence, these suggestions might have affected our participants and caused information chaos about this disease.

Although the national guidelines do not suggest antiviral prophylaxis against COVID-19, $57 \%$ of the participants agreed that using prophylactic antiviral drugs were required for the prevention of COVID-19. We perceived that the news telling that these protective drugs are effective on this virus has caused medical personnel to take such drugs thinking of preserving their lives. One-third of the participants thought that they do not have enough knowledge about such protective treatments. In addition, $40 \%$ of the participants declared that they have suffered a shortage of protective equipment when caring for COVID-19 patients. Based on 
these data, it can be concluded that EMS workers need more often and more practical professional training.

Some limitations should be noted when interpreting our findings. The small sample size is the main strength of the study. The relatively low response rate from EMS staff, sample clustering, and the cross-sectional design of the study are regarded as limitations.

\section{CONCLUSION}

As a consequence, although emergency workers have sufficient basic knowledge about COVID-19, there is a need for postgraduate training in many subjects. Professional organizations and non-governmental organizations should cooperate in this regard.

\section{Acknowledgments}

Authors acknowledge that the copyright of this paper is transferred to the property of your journal.
Nobody else contributed towards the study by making substantial contributions to the concept, design, data acquisition, analysis and interpretation, or was involved in drafting the manuscript or revising it critically for important intellectual content. This research received no grant from any funding agency in the public, commercial, or not-for-profit sectors.

\section{Author's Contribution}

A.V. planned the methodology and wrote the manuscript; E.G. was responsible for data management and reporting collected data; A.Ö. provided access to crucial research components (personnel, equipment, environment), and was responsible for the Ethical Approval process; F.A.K. was responsible for the statistical interpretation and conclusion of the results; O.K. built the hypothesis of the article and reviewed the article scientifically, besides its spelling and grammar, before submission.

\section{RESUMO}

OBJETIVO: Um bom conhecimento sobre a doença por coronavírus 2019 (COVID-19) entre profissionais de saúde é essencial para manter os sistemas de saúde ativos e controlar o surto. Nosso objetivo foi investigar o conhecimento e as atitudes dos funcionários do serviço médico de emergência (EMS) que lutam com o COVID-19 na vanguarda.

MÉTODOS: Um total de 400 trabalhadores do SME (médicos, enfermeiros, técnico de emergência médica, paramédicos e motoristas de ambulância) foram incluídos neste estudo. Conhecimento, atitude e comportamentos preventivos para COVID-19 foram avaliados usando um questionário on-line.

RESULTADOS: Um total de 275 trabalhadores do SME participou do estudo com uma taxa de resposta de 68,8\%. Os entrevistados relataram que as maiores fontes comuns de conhecimento sobre COVID-19 foram as mídias sociais e a televisão ( $n=240,88 \%$ ). No geral,> 96\% dos participantes tinham conhecimento adequado sobre as rotas de transmissão do COVID-19. Entre os entrevistados, $36 \%$ deles desconheciam a técnica correta de lavar ou esfregar as mãos. Além disso, $78 \%$ dos participantes tinham pouco conhecimento sobre desinfecção de pisos e superfícies. A maioria dos participantes exibiu atitudes imprecisas em relação ao uso de equipamentos preventivos pessoais. Mais da metade dos trabalhadores do SME (52\%) concordou que a máscara cirúrgica não é suficiente durante os procedimentos que não geram aerossol. Além disso, uma proporção significativa dos participantes (66\%) percebeu que a máscara N95 é necessária.

CONCLUSÕES: Como conseqüência, embora os trabalhadores de emergência tenham conhecimento básico suficiente sobre o COVID-19, há necessidade de treinamento de pós-graduação em muitas disciplinas.

PALAVRAS-CHAVE: doença de coronavírus 2019, serviço médico de emergência, conhecimentos e atitudes, questionare

\section{REFERENCES}

1. Deng S-Q, Peng $\mathrm{H}-\mathrm{J}$. Characteristics of and public health responses to the Coronavirus disease 2019 outbreak in China. J Clin Med 2020;9:575.

2. Zhu N, Zhang D, Wang W, Li X, Yang B, Song I, et al. A novel coronavirus from patients with pneumonia in China. 2019. N Engl J Med 2020;382:727-33.

3. Institute of Medicine (US) Forum on Microbial Threats, Ensuring an Infectious Disease Workforce: Education and Training Needs for the $21^{\text {st }}$ Century. Washington (DC): National Academies Press (US); 2006.

4. Lai CC, Shih TP, Ko WC, Tang HJ, Hsueh PR. Severe acute respiratory syndrome coronavirus 2 (SARS-CoV-2) and corona virus disease-2019
(COVID-19): the epidemic and the challenges. Int I Antimicrob Agents 2020;55:105924.

5. Republic of Turkey Ministry of Health's COVID-19 Guide. https://hsgm. saglik.gov.tr/depo/COVID-19/rehberler/COVID-19_Rehberi.pdf. Last accessed April 1, 2020.

6. Chang D, Xu H, Rebaza A, Sharma L, Cruz CSD. Protecting health-care workers from subclinical coronavirus infection. Lancet Respir Med 2020;8:13.

7. Wang D, Hu B, Hu C, Zhu F, Liu X, Zhang J, et al. Clinical characteristics of 138 hospitalized patients with 2019 novel coronavirus-infected pneumonia in Wuhan, China. JAMA 2020;323:1061-9. 
8. The Lancet. COVID-19: protecting health-care workers. Lancet 2020:395:922.

9. $\operatorname{Kim}$ JS, Choi JS. Middle East respiratory syndrome-related knowledge, preventive behaviours and risk perception among nursing students during outbreak. J Clin Nurs 2016;25:2542-9.

10. Albarrak Al, Mohammed R, A Elayan A, Al Fawaz F, Al Masry M, Al Shammari $M$, et al. Middle East Respiratory Syndrome (MERS): Comparing the knowledge, attitude and practices of different health care workers. [published online ahead of print]. I Infect Public Health. 2019;doi:10.1016/j. jiph.2019.06.029.

11. Mohammad HT, Roham B, Ramin S. COVID-19 and Iranian Medical Students; A Survey on Their Related-Knowledge, Preventive Behaviors and Risk Perception. Arch Iran Med 2020;23:249-54.

12. Turkey Republic Health Ministry press report. https://COVID-19bilgi.saglik. gov.tr/tr/ 30 April 2020.

13. Khan S, Khan M, Maqsood K, Hussain T, Noor-Ul-Huda, Zeeshan M. Is Pakistan prepared for the COVID-19 epidemic? A questionnaire-based survey. J Med Virol 2020; 10.1002/jmv.25814.

14. Prescott K, Baxter E, Lynch C, Jassal S, Bashir A, Gray J. COVID-19: How prepared are front line healthcare workers in England? I Hosp Infect 2020;105:142-5.

15. Larson HJ. The biggest pandemic risk? Viral misinformation. Nature 2018;562:309.

16. Wilson ME, Chen LH. Travellers give wings to novel coronavirus (2019nCoV). J Travel Med 2020;27:taaa015.
17. Waszak PM, Kasprzycka-Waszak W, Kubanek A. The spread of medical fake news in social media-the pilot quantitative study. Health Policy Technol 2018;7,115-8.

18. World Health Organization. Novel Coronavirus(2019-nCoV).Situation Report - 13. https://www.who.int/docs/default-source/coronaviruse/ situation-reports/20200202-sitrep-13-ncov-v3.pdf?sfvrsn=195f4010_6. Accessed February 18, 2020.

19. WHO Guidelines on Hand Hygiene in Health Care: a Summary https:// www.who.int/gpsc/5may/tools/who_guidelines-handhygiene_summary. pdfWHO/IER/PSP/2009.07. July 2009.

20. World Health Organization. Advice on the use of masks in the context of COVID-19: interim guidance. https://apps.who.int/iris/handle/10665/331693. 6 April 2020.

21. Hemila H. Vitamin C intake and susceptibility to pneumonia. Pediatr Infect Dis | 1997;16:836-7.

22. Fowler AA, Truwit ID, Hite RD, Morris PE, DeWilde C, Priday A, et al. Effect of Vitamin C Infusion on Organ Failure and Biomarkers of Inflammation and Vascular Injury in Patients With Sepsis and Severe Acute Respiratory Failure: The CITRIS-ALI Randomized Clinical Trial. JAMA 2019;322:1261-70.

23. Fujii T, Luethi N, Young PJ, Frei DR, Eastwood GM, French Cl, et al. Effect of Vitamin C, Hydrocortisone, and Thiamine vs Hydrocortisone Alone on Time Alive and Free of Vasopressor Support Among Patients With Septic Shock: The VITAMINS Randomized Clinical Trial. IAMA 2020;323:423-31.

24. Grant WB, Lahore H, McDonnell SL, Baggerly CA, French CB, Aliano JL, et al. Evidence that Vitamin D Supplementation Could Reduce Risk of Influenza and COVID-19 Infections and Deaths. Nutrients 2020;12:988.

25. McCartney DM, Byrne DG. Optimisation of Vitamin D Status for Enhanced Immuno-protection Against COVID-19. Ir Med J 2020;113:58. 